\title{
JOANNA LUC
}

(Kraków)

\section{POZNANIE METAFIZYCZNE W ŚWIETLE ROZRÓŻNIEŃ ABSTRAKCYJNE-KONKRETNE I OGÓLNE-JEDNOSTKOWE}

\section{Wprowadzenie}

We współczesnej ontologii analitycznej często podkreśla się odrębność dwóch przeciwstawień - tego, co konkretne, temu, co abstrakcyjne oraz tego, co jednostkowe, temu, co ogólne ${ }^{1}$. To drugie rozróżnienie związane jest z możliwością wielokrotnego wystąpienia - jednostki są niepowtarzalne, natomiast np. ogólna własność może przysługiwać wielu jednostkom, w różnych chwilach i miejscach. Z kolei za konkret należy uważać „pełny” byt, dookreślony pod każdym względem, zaś abstrakt jest tym, co by z owego konkretu „pozostało”, gdyby „pozbawiać” go kolejnych aspektów czy określeń - nie może on więc zaistnieć samodzielnie, potrzebuje do tego celu dookreślenia, „dopełnienia” do konkretu. Powyższa charakterystyka jest nieścisła i może być doprecyzowana, np. przez przyjęcie tylko niektórych cech za definiujące daną kategorię, a innych za pochodne lub nawet kontrowersyjne. $\mathrm{W}$ tej pracy zamierzam jednak przyjąć ją mniej więcej w takiej formie i w jej świetle rozważyć zagadnienie poznania metafizycznego na tle innych rodzajów poznania oraz problemy wynikające ze znajdowania się metafizyki w tym, a nie innym miejscu, które dawały o sobie znać w historii tej dziedziny.

Przedmiotem moich dociekań będzie odmiana metafizyki, którą można nazwać realistyczną, a do której zaliczam przede wszystkim metafizykę klasyczną,

\footnotetext{
1 Por. np. A. Chrudzimski, Realistyczne teorii uniwersaliów, [w:] S. Kołodziejczyk (red.), Przewodnik po metafizyce, Kraków 2011, s. 131-133. Dla skrótowości będę je nazywać „kategoriami”. Nie chodzi tu oczywiście o kategorie w sensie Arystotelesowskim. Same rozróżnienia rzecz jasna nie są współczesne, tylko wcześniejsze.
} 
czyli tworzoną przez Arystotelesa i średniowiecznych filozofów nim się inspirujących; dalej, jej kontynuację w postaci współczesnego neotomizmu, a także część metafizyki uprawianej w ramach filozofii analitycznej ${ }^{2}$ (przy czym $\mathrm{w}$ tej pracy skoncentruję się głównie na przykładach związanych z autorami klasycznymi). Wszystkie wymienione prądy myślowe łączy przekonanie, że możliwa jest wiedza o rzeczywistości „samej w sobie” (określenie to może nie jest historycznie adekwatne, ale sądzę, że trafnie oddaje analizowaną tu postawę, przywodząc przy tym od razu na myśl zarzuty, jakie wobec niej wysuwano). Inne rodzaje metafizyki zostaną tu pominięte, co nie ma sugerować ich mniejszego prawa do określania się tym mianem, a jest tylko roboczym ograniczeniem przedmiotu analiz.

Zapewne nie wszystkie wyniki tych rozważań zależą od takiego „realistycznego" pojmowania metafizyki, wymagałoby to jednak dodatkowej analizy. Chciałabym jeszcze odróżnić ten rodzaj realizmu od innego, węższego rozumienia tego pojęcia, jakie pojawia się wśród niektórych neotomistów ${ }^{3}$. Tam metafizyka realistyczna, mająca za punkt wyjścia istniejący, doświadczany byt, przeciwstawiona jest ontologii, wychodzącej od idei w umyśle i badającej to, co możliwe. Moje rozumienie terminu „metafizyka realistyczna” nie rozstrzyga nic na temat punktu wyjścia ani metody, dopuszcza także, że na drodze do realnego bytu potrzebne będzie rozważenie możliwości nie znajdujących odzwierciedlenia w rzeczywistości - zakłada się tylko, że koniec końców, nieważne po jak wielu meandrach, da się coś o bycie prawdziwie poznać.

\section{Dwa przeciwstawienia a natura poznania}

Na początku zauważmy, że przedstawione na początku dwa przeciwstawienia są rzeczywiście różne. Warto na to zwrócić uwagę, ponieważ spontanicznie niekiedy je mieszamy, traktując ogólność i abstrakcyjność z jednej strony, zaś jednostkowość i konkretność z drugiej jako synonimy. Oczywiście, nie można wykluczyć, że w rzeczywistości są one równozakresowe. O tym, że nie znaczą tego samego, świadczą ewidentnie różne ich charakterystyki podane na początku oraz fakt, że dzięki ich wyraźnemu odgraniczeniu filozofowie rozważają pewne nietrywialnie połączenia, np. tzw. tropy, które są zarazem abstrakcyjne i jednostkowe;

\footnotetext{
2 Na przykład Armstrong, Lowe, Campbell. Przeciwstawiam nurt „realistyczny” nurtowi „konceptualistycznemu" (np. Strawson), wedle którego zadaniem metafizyki jest tylko badanie funkcjonujących schematów pojęciowych.

3 P. Jaroszyński, Metafizyka czy ontologia, Lublin 2011.
} 
istnieją nawet ontologie traktujące je jako jedyną realną bądź jedyną nieredukowalną do innych kategorię ${ }^{4}$.

Po drugie, jakkolwiek oba przeciwstawienia miały w zamyśle (każde z osobna) dzielić wszystko to, co da się pomyśleć, na dwie rozłączne i zupełne klasy, to można je również potraktować jako stopniowalne. Mniej problematyczne jest to w przypadku abstrakcyjności i konkretności - mianowicie dany obiekt jest bardziej abstrakcyjny od tego, z czego został wyabstrahowany i mniej abstrakcyjny od tego, co można z niego wyabstrahować. Co do ogólności i jednostkowości, sprawa jest nieco bardziej subtelna, gdyż zaangażowane są tu modalności - ten obiekt jest ogólny, który może wielokrotnie wystąpić, nawet jeśli faktycznie nigdy mu się to nie przytrafi. Porównywanie ilości możliwych wystąpień jest trudne lub niemożliwe do wykonania, a bez tego nie można stworzyć jakiejś jednej skali ogólności, na której można by umieścić wszystkie obiekty. Wydaje się jednak pożyteczne podzielenie ogólności na właściwą i całkowitą, przy czym ta druga oznacza konieczne występowanie w (czy też raczej „w”) każdym konkrecie. Dla celów dalszych rozważań nazwę „rejonem kategorialnym” lokalizację w określonym miejscu spektrum pomiędzy abstrakcyjnością a konkretnością wraz z podaniem jednej z 3 charakterystyk: jednostkowość, ogólność właściwa, ogólność całkowita (czyli w sumie dwie „współrzędne kategorialne”, po jednej dla każdego z dwóch wyjściowych przeciwstawień).

Mając dane te rozróżnienia, możemy zapytać, gdzie lokują się na tych dwóch skalach różne rodzaje poznania oraz który rejon kategorialny jest poznawalny w sposób najłatwiejszy czy też (bardziej kontrowersyjne sformułowanie) bardziej naturalny dla umysłu ludzkiego. W dalszej kolejności warto byłoby także zapytać, skąd biorą się trudności po przekroczeniu granic tego rejonu.

Poznanie pojecciowe, jakim operuje wiedza potoczna i nauki szczegółowe, wiąże się z abstrakcją i dotyczy wielu jednostek, zatem (być może z paroma wyjątkami) możemy je umieścić w kategorii ogólności właściwej oraz w pewnym oddaleniu od obu skrajnych biegunów na spektrum pomiędzy tym, co abstrakcyjne, a tym, co konkretne. Jeśli faktycznie tam znajduje się wiedza potoczna, to jest to również rejon najłatwiej dostępny poznawczo ${ }^{5}$.

\footnotetext{
4 Na przykład K. Campbell, Abstract Particulars. Philosophical Theory, Cambridge 1990, s. $1-26$.

5 W przypadku zmatematyzowanych nauk szczegółowych należałoby dodać istotne zastrzeżenia. Nie występuje tu już ta łatwość poznawcza - nauki takie nawet dla osób nimi się zajmujących wymagają dużego wysiłku intelektualnego, pewna łatwość może być ewentualnie nabywana. Operują one bowiem tzw. metodą hipotetyczno-dedukcyjną, którą w tym kontekście zasadnie jest nazwać konstrukcyjno-dedukcyjną - duża część badań w ogóle nie dotyczy obiektów rzeczywistych, ale pewnych skonstruowanych systemów rachunkowych. Zagadnienie to jednak nie jest związane z głównym tematem tych rozważań.
} 
Co zatem znalazło się poza rejonem „łatwości” poznawczej? Wszystkie „krańce", a więc z jednej strony jednostkowość i ogólność całkowita, a z drugiej (pełna) konkretność i wysokie stopnie abstrakcji. Jeżeli przyjąć, że celem poznania potocznego jest przede wszystkim zorientowanie się w świecie, pozwalające na osiąganie praktycznych celów, ale w sposób nie wymagający do realizacji zbyt dużych kosztów, to taka lokalizacja okazuje się być bardzo udana. Zwykle „przydatne” własności obiektów to te, które pozwalają nam je odróżnić od innych (wykluczamy ogólność całkowitą), ale też są dzielone przez pewną grupę obiektów podobnych dzięki temu możemy raz zdobytą wiedzę wykorzystać wielokrotnie (wykluczamy jednostkowość). Pełna znajomość wszystkich aspektów obiektu (wysoki stopień konkretności) może dawać pewne korzyści, ale zbyt duża ilość informacji utrudniałaby szybkie wydobycie tej jej części, z której w danej sytuacji warto byłoby skorzystać; z kolei zbyt abstrakcyjna znajomość obiektu nie dawałaby wiedzy o jego specyfice, więc znów rejon „umiarkowany” wydaje się być optymalny.

W tym miejscu warto wrócić do głównego tematu naszych rozważań, jakim miało być poznanie metafizyczne. Hipoteza stawiana w tej pracy jest taka: metafizyka lokuje się w rejonie ogólności, często całkowitej oraz na wysokich poziomach abstrakcji i z tego wynikaja jej trudności poznawcze. Wspomnijmy tylko marginalnie, że istnieli metafizycy explicite odrzucający ten pogląd - np. Henri Bergson wiązał poznanie abstrakcyjne i ogólne wyłącznie z naukami szczegółowymi, natomiast metafizykę lokował w rejonie jednostkowości i konkretności ${ }^{6}$ (czyli, co znamienne, również poza rejonem „łatwym” poznawczo).

\section{Problemy z abstrakcją i ogólnością a historia metafizyki}

Chciałam teraz krótko przyjrzeć się kilku historycznym przykładom, które w moim przekonaniu potwierdzają dokonane wcześniej ustalenia na temat „lokalizacji kategorialnej" poznania metafizycznego i przy okazji pokazać, jak owe ustalenia moga posłużyć do wyjaśnienia trudności poznawczych pojawiających się przy uprawianiu metafizyki.

Myślenie pojęciowe zawsze jest w jakiejś mierze abstrakcyjne, ale istotny jest tė̇ stopień owej abstrakcyjności. Historycznie rzecz biorąc, przejście do wyższego jej stopnia wydaje się być kluczowym elementem w rozwoju myśli ludzkiej.

Antropolodzy badający społeczności pierwotne wskazują na stosunkowo mały rozwój pojęć abstrakcyjnych - np. zamiast myśleć w kategoriach przestrzeni

6 Zob. np. H. Bergson, Myśl i ruch. Dusza i ciało, przeł. P. Beylin, K. Błeszyński, Warszawa 1963. 
„wszędzie takiej samej”, ludzie tacy operują pojęciem odległości przestrzennej zależnej od tego, ile czasu zajmuje dotarcie do danego miejsca bądź jakie jest podobieństwo kulturowe ludzi tam żyjaccych ${ }^{7}$. Można to tłumaczyć w ten sposób, że nie umieją oni (ale zapewne także nie potrzebują) wyabstrahować z całości przestrzenno-zdarzeniowej aspektu czysto przestrzennego. Za moment przełomowy w „historii abstrakcji” uważa się często właśnie powstanie filozofii, może to nawet być kryterium odróżniania myśli filozoficznej od ją poprzedzającej. Sprawa jest jednak subtelna - Kirk i Raven podają przykłady kosmogonii „mieszanych” (np. Alkman, Ferekydes), co do których badacze spierają się, na ile pojęcia w nich używane były jeszcze „mitologiczne” ${ }^{8}$. Problem ten może się jednak pojawić nawet w przypadku postaci klasycznie uważanych za filozofów, ponieważ słowo bardziej „konkretne” może być używane do wyrażania bardziej abstrakcyjnych treści lub na odwrót, zatem na podstawie samych słów może być trudno rozstrzygnąć, z którą sytuacją mamy do czynienia.

Problem ten nie jest właściwy jedynie początkom myśli filozoficznej. Wzrost liczby używanych pojęć o dużym stopniu abstrakcyjności i ogólności zwiększa nawet ryzyko nieporozumień. Oba przedstawione na początku rozróżnienia mają konsekwencje epistemologiczne. Jeśli przyjmiemy założenie, że umysł spontanicznie ciąży ku rejonom kategorialnym łatwiej mu dostępnym i gdy pojawi się coś spoza nich, to próbuje potraktować to analogicznie lub wręcz nieświadomie sprowadzić do tego, co lepiej znane, to otrzymamy następujący obraz. W sytuacji, gdy przedmiot badania jest wysoce abstrakcyjny, umysł może mieć tendencję do „dopełniania” go do konkretu, a więc przypisywać mu te aspekty, z którymi w realnych bytach faktycznie bywa on powiązany, ale które w danej analizie właśnie miały zostać pominięte. Problem z ogólnością jest powiązany, ale nieco inny. Gdy jakaś cecha posiada duży stopień ogólności, a więc występuje w wielu bytach, to trudno ją zauważyć i wydzielić. Jeszcze trudniejsze będzie odróżnienie dwóch cech o wysokim stopniu ogólności, które zawsze współwystępują, przynajmniej w znanych nam bytach.

Ciekawym przykładem, na razie spoza filozofii, na trudności z abstrakcją, jest wykorzystanie przez alchemików arystotelesowskiej koncepcji materii pierwszej ${ }^{9}$. Koncepcja Arystotelesa nie dopuszczała możliwości samodzielnego istnienia takiego tworu. Można to zinterpretować w naszych kategoriach w ten sposób, że materia i forma to dwa aspekty bytu konkretnego, które są z niego abstrahowane. Natomiast w teorii średniowiecznych alchemików europejskich materia pierwsza

7 E. Evans-Pritchard, Religia Nuerów, przeł. K. Baraniecka i M. Olszewski, Kęty 2007, s. $22-23$.

8 G. S. Kirk, J. E. Raven, M. Schofield, Filozofia przedsokratejska, przeł. J. Lang, Warszawa-Poznań 1999, s. 61-83.

9 Zob. np. R. Bugaj, Hermetyzm, t. 1-2, Warszawa 1998. 
jest stanem, do którego można doprowadzić konkretny obiekt, jeżeli podda się go odpowiedniej obróbce. Pewne cechy koncepcji arystotelesowskiej zostały zachowane, np. nieograniczona potencjalność takiej materii, możliwość przyjmowania przez nią dowolnych form, znikła jednak jej niekonkretność, związana z niemożliwością istnienia bez uzupełnienia w postaci formy.

Na kilka przykładów mogących zilustrować bronioną tu tezę wskazują neotomiści. Zdaniem E. Gilsona ${ }^{10}$, jeden z głównych problemów terminologicznych metafizyki wiąże się z rozróżnieniem aspektu czasownikowego i rzeczownikowego bycia, tzn. samego „być” od „być bytem”. W historii języka, w tym języka metafizyki, termin używany dla wyrażenia tego pierwszego (esse) zaczął coraz bardziej nabywać konotacji rzeczownikowych, tak że w końcu w oznaczaniu samego faktu bycia musiało go zastąpić inne słowo (existere), które z kolei pierwotnie wiązało się raczej z genetycznym aspektem bycia (wywodzenie się z czegoś). Pierwsze zjawisko można potraktować jako przykład problemów z abstrakcją: termin „być” okazał się na tyle abstrakcyjny, że „dopełniono” go do bycia czegoś, jakiegoś konkretnego bytu, co utrudnia wyróżnienie samego bytowania jako odrębnego aspektu takiego bytu. Z kolei drugie przesunięcie znaczeniowe Gilson tłumaczy w ten sposób, że skoro jedynym znanym nam sposobem bycia jest istnienie (a więc otrzymywanie bytu od czegoś innego), to słowo „istnieć” mogło zacząć zastępować słowo „być”. Byłby to więc przykład problemów z ogólnością - we wszystkich znanych nam przypadkach jakieś treści zawsze współwystępują, więc mamy trudności z odróżnieniem ich.

Inny neotomistyczny przykład dotyczy również historii pojęcia esse. Mianowicie wskazuje się na Tomasza z Akwinu jako tego, który z jednej strony odróżnił istotę (essentia) od istnienia (esse), ale z drugiej strony miał cały czas na uwadze ich wzajemne związki - nie ma istot pozbawionych istnienia, a istnienie jest zawsze istnieniem jakiejś istoty. Zdaniem M. Krąpca następcy Tomasza nie zawsze byli równie subtelni - podawany jest przykład Idziego Rzymiania ${ }^{11}$, który potraktował istnienie i istotę jako dwie różne rzeczy (res). Jeżeli takie przypisanie owemu scholastykowi „reizacji” istnienia jest trafne, to byłby to kolejny przykład problemów z abstrakcją, nieco inny niż wcześniej. W przypadku przytoczonym za Gilsonem pojęcie abstrakcyjne zostało dopełnione do bardziej konkretnego, natomiast tutaj bez „zmniejszania” jego abstrakcyjności zostało błędnie potraktowane jako wyrażające konkret. Trafność tych uwag zależy oczywiście od poprawności określonych interpretacji pism scholastyków, lecz nawet jeśli zawierają one błędy, to i tak tutaj najważniejsze jest wskazanie samej możliwości ryzyka - jego fak-

10 E. Gilson, Byt i istota, przeł. D. Eska i J. Nowak, Warszawa 2006, s. 7-17.

11 M. Krąpiec, Struktura bytu. Charakterystyczne elementy systemu Arystotelesa $i$ Tomasza z Akwinu, Lublin 1963, s. 308-332. 
tyczne realizowanie się jest niewątpliwe, kontrowersyjne mogą być tylko analizy konkretnych przypadków wystąpienia.

$\mathrm{Na}$ jeszcze jeden problem $\mathrm{z}$ istnieniem wskazuje Ch. Kahn, wedle którego pojęcie istnienia długo miało $\mathrm{w}$ filozofii konotacje przestrzenne ${ }^{12}$. Byłby to tym razem problem z ogólnością - znamy z doświadczenia głównie byty przestrzenne, więc mamy trudność z ujęciem aspektu egzystencjalnego bez przestrzennego, z którym on (dla nas) zwykle współwystępuje. Warto zauważyć, że metaforyka przestrzenna pojawia się często w metafizyce (przykładem może być chociażby wprowadzone w tym tekście pojęcie obszaru kategorialnego) i naukach (np. ilustrowanie abstrakcyjnych zależności na wykresach), co świadczy o silnym dążeniu umysłu ludzkiego do takiego sposobu myślenia.

Kolejnym (i ostatnim rozważanym w ramach tej pracy) zagadnieniem, które można zanalizować w świetle dokonanego tu rozróżnienia, jest spór między zwolennikami analogiczności (lub wieloznaczności) i jednoznaczności bytu (czy też pojęcia „byt”). W szczególności, przyjrzyjmy się argumentom Tomasza z Akwinu przeciwko jednoznaczności orzekanego o Bogu i stworzeniach. Filozof ten pisze np. ${ }^{13}$ :

Jeśli jakiś skutek jest gatunkowo na poziomie przyczyny, to można orzekać nazwę jednoznacznie tylko wtedy, gdy skutek ten przyjmuje gatunkowo tę samą formę, zgodnie z tym samym sposobem istnienia. (...) Inne rzeczy zaś, nawet gdyby otrzymały [od Boga] zupełnie tę samą formę [jaka jest w Jego umyśle], to jednak nie zgodnie z tym samym sposobem istnienia.

W innym miejscu czytamy ${ }^{14}$ :

Żadne zaś stworzenie, ponieważ jest skończone, nie może się równać mocy pierwszego czynnika działającego, gdyż jest nieskończona. Stąd nie jest możliwe, by podobieństwo do Boga mogło być jednoznacznie przyjęte w stworzeniu.

I jeszcze $^{15}$ :

Bóg zaś ma się do istnienia inaczej niż jakiekolwiek stworzenie, ponieważ sam jest swoim istnieniem, co nie przysługuje żadnemu stworzeniu. Stąd w żaden sposób nie można orzekać istnienia jednoznacznie o Bogu i stworzeniu.

Na wszystkie te argumenty zwolennik jednoznaczności mógłby odpowiedzieć następująco: przedmiotem sporu było pojęcie istnienia, a wszystkie przytoczone

12 Ch. Kahn, Język i ontologia, przeł. B. Żukowski, Kęty 2008, s. 24-30.

13 Tomasz z Akwinu, Summa contra gentiles, t. 1, przeł. Z. Włodek, W. Zega, Poznań 2003, s. 102 .

14 Tamże, s. 213.

15 Tomasz z Akwinu, Kwestie dyskutowane o mocy Boga, przeł. Z. Bomert i in., Kęty 2008, s. 213 . 
tu argumenty zabraniają jednoznacznego orzekania go ze względu na coś innego niż istnienie właśnie. Niewątpliwie zachodzą fundamentalne różnice między Bogiem a stworzeniami, jednakże (przynajmniej te przytoczone) nie są różnicami pod względem istnienia, tylko pod innymi względami (formy i sposobu istnienia, skończoności lub nieskończoności mocy, relacji istnienia do istoty). Przeciwnik jednoznaczności byłby w takim ujęciu tym, kto nie dość dokładnie wyabstrahował istnienie z innych aspektów bytu, z którymi zawsze ono współwystępuje, ma więc problem i z abstrakcyjnością (automatyczne dopełnianie istnienia pewnymi innymi treściami) i z ogólnością (w doświadczeniu te treści zawsze współwystępują z istnieniem - nie spotykamy samego istnienia, tylko byt istniejący, który ma pewną formę, istotę, itd.).

Podsumowując, zaproponowane tu podejście pozwala analizować różne problemy metafizyczne nie tyle od strony merytorycznej (choć zawiera też pewne tezy ściśle metafizyczne), co od strony trudności poznawczych z nimi związanych. Jego trafność lub jej brak należałoby więc oceniać na podstawie tego, jak radzi sobie z wyjaśnieniem najważniejszych sporów w metafizyce i czy rzeczywiście najwięcej kontrowersji w tej dziedzinie lokuje się tam, gdzie byśmy się ich (na podstawie naszych założeń) spodziewali. Powyższe analizy są bardzo wybiórcze jeśli chodzi o dobór przykładów, nie zostały również rozważone krytycznie żadne potencjalne kontrprzykłady, zatem nie mogą być one w żadnej mierze uważane za rozstrzygające. Stanowią jedynie zarys pewnej interesującej perspektywy badawczej.

\section{Cognition in metaphysics in the light of distinctions: abstract-concrete and universal-particular}

\section{Summary}

The aim of this paper is to present an approach in metaphysics/ ontology, which is founded on two distinctions: abstract-concrete and universal-particular. To different cognitive issues one can assign different "categorical coordinates", namely: a place in the spectrum of abstractness and one of the three following characteristics: particularity, proper universality, total universality. The thesis of this paper is that metaphysics should be located in the region of universality and high degrees of abstractness. Such a localization is connected with specific cognitive difficulties which are present in this branch of philosophy. I demonstrate some problems from the history of philosophy which could be interpreted as caused by these difficulties. Applicability of my thesis to such concrete cases is treated as its indirect justification.

Key words: cognition, metaphysics, universality, particularity, abstraction

Słowa kluczowe: poznanie, metafizyka, uniwersalność, szczegółowość, abstrakcja 


\section{Bibliografia}

D. Armstrong, A World of States of Affairs, Cambridge 1997.

Arystoteles, Metafizyka, t. 1-2, przeł. M. A. Krąpiec, A. Maryniarczyk, Lublin 1996.

H. Bergson, Myśl i ruch. Dusza i ciało, przeł. P. Beylin, K. Błeszyński, Warszawa 1963.

R. Bugaj, Hermetyzm, t. 1-2, Warszawa 1998.

K. Campbell, Abstract Particulars. Philosophical Theory, Cambridge 1990.

A. Chrudzimski, Realistyczne teorii uniwersaliów, [w:] S. Kołodziejczyk (red.), Przewodnik po metafizyce, Kraków 2011.

F. Copleston, Historia filozofii, t. 2, przeł. H. Bednarek, Warszawa 2004.

E. Evans-Pritchard, Religia Nuerów, przeł. K. Baraniecka i M. Olszewski, Kęty 2007.

E. Gilson, Byt i istota, przeł. D. Eska i J. Nowak, Warszawa 2006.

Idzi Rzymianin, Twierdzenia o istnieniu i istocie, przeł. J. Surzyn, Kęty 2005.

P. Jaroszyński, Metafizyka czy ontologia, Lublin 2011.

Ch. Kahn, Język i ontologia, przeł. B. Żukowski, Kęty 2008.

G. S. Kirk, J. E. Raven, M. Schofield, Filozofia przedsokratejska, przeł. J. Lang, Warszawa-Poznań 1999.

M. Krąpiec, Struktura bytu. Charakterystyczne elementy systemu Arystotelesa i Tomasza z Akwinu, Lublin 1963.

E. J. Lowe, Recent Advances in Metaphysics, http://mba.eci.ufmg.br/downloads/pos/ Recent\%20advances\%20in\%20methapysics_Lowe.pdf (dostęp 7.06.2013).

P. F. Strawson, Indywidua: próba metafizyki opisowej, przeł. B. Chwedeńczuk, Warszawa 1980.

Tomasz z Akwinu, Kwestie dyskutowane o mocy Boga, przeł. Z. Bomert i in., Kęty 2008.

Tomasz z Akwinu, Summa contra gentiles, t. 1, przeł. Z. Włodek, W. Zega, Poznań 2003.

Joanna Luc, Instytut Filozofii, Uniwersytet Jagielloński, ul. Grodzka 52, Pl-31-044 Kraków, e-mail: joanna.luc90@gmail.com 